\title{
Optimal Strategies for Realizing the Value of Open University Learning Support Services in the "Internet+" Era
}

\author{
Huijun Fu \\ Teaching Center, Zhejiang Open University, Hangzhou, China \\ Email: fuhj@zjtvu.edu.cn
}

How to cite this paper: Fu, H. J. (2022). Optimal Strategies for Realizing the Value of Open University Learning Support Services in the "Internet+" Era. Open Journal of Social Sciences, 10, 183-192. https://doi.org/10.4236/jss.2022.101016

Received: December 24, 2021

Accepted: January 17, 2022

Published: January 20, 2022

Copyright (อ 2022 by author(s) and Scientific Research Publishing Inc. This work is licensed under the Creative Commons Attribution International License (CC BY 4.0).

http://creativecommons.org/licenses/by/4.0/

\section{(c) (i) Open Access}

\begin{abstract}
Learning support services are the core and key of the quality assurance system of distance education in open universities. How to provide learners with high-quality learning support services and realize the value of learning support services in the "Internett" era is an urgent issue to be solved. Based on the analysis of the current deficiencies in the learning support services of open universities, combined with the advantages of the further integration of technology and education in the Internet era, this paper puts forward the path and countermeasures that can meet the learning needs of learners and provide them with standardized, individualized and diversified learning support services.
\end{abstract}

\section{Keywords}

Open University, Distance Education, Learning Support Service, Personalization

\section{Introduction}

Learning support service is a distinct feature of distance education that distinguishes distance education from other forms of education. As an important component of distance education, it develops along with the evaluation of distance education. The "Internet+" era has brought diversification of distance education, and has also promoted further development of learning support services in distance education. According to the "Opinions on Running an Open University" issued by the Ministry of Education, open universities should adhere to open education, serve the learning of all people, adapt to the needs of education for all lifelong learning, provide the society with educational resources to the greatest 
extent, and provide diversified educational services (Tang, Zuo, \& Zhang, 2020). The "National Open University Construction Plan" pointed out that based on the application and development of the hybrid teaching model for online learners, open universities should focus on the establishment of a large-scale remote reception service team that combines professionalization and informatization to enhance remote learning support level, strengthen the teaching interaction with learners and provide learners with appropriate personalized distance learning support services (Tang, Zuo, \& Zhang, 2020). The realization of the value of learning support services has become an important factor affecting the high-quality development of open universities. How to effectively carry out learning support services in the Internet age is a problem worthy of exploration.

In 1978, "Continuity of Concern for Student in a System of Learning at a Distance" written by David Sewart's from British Open University first systematically discussed distance education issues related to learning support service (Sewart, 1978). The following year, the British scholar John. A. Bath put forward the concept of "two-way communication" and applied it to correspondence education. John. A. Bath believed that two-way communication is the center of the correspondence teaching process and emphasized the guiding role of teachers in correspondence education, which has become the basic theory of learning support services (Bath, 1979). Chinese scholars have been involved in the research in this field since the beginning of the 21st century. Scholars such as Ding Xingfu, Chen Li, Zhou Wei, Ding Xin, Xue Wei have all conducted specialized research on learning support services. The content mainly focuses on the basic cognition of learning support services such as connotation, characteristics, functions, and elements, and the introduction of related foreign theories.

Learning support services denote the sum of various information, resource, and personnel services provided by distance learning colleges and their teachers for remote students. Its purpose is to guide, help and promote students' autonomous learning and improve the quality and effect of distance learning (Ding, 2001). Different from traditional education, open distance education has two outstanding characteristics: first, learners focus on self-study; second, learners are separated from teachers and other learners in time and space. Based on these characteristics, learning support services need to be personalized, interactive, continuous, open, and systematic. It can be seen that in the distance teaching of open universities, learning support services need to focus on the learner, and provide high-quality and diverse services. At the same time, with the development of personalized learning needs, learners have more extensive and flexible requirements for learning, which brings about higher requirements for related learning support services. Therefore, in the context of the new era, in order to meet the learning needs of learners, open universities should actively explore ways and methods to realize the value of learning support services in the Internet era. 
Since its establishment in 2012, the National Open University, as a new type of university, has been actively committed to continuously satisfying the diverse learning needs of society (Yang, 2011). In terms of the close relationship between learning needs and learning support services, learning needs can be met through diversified learning support services, and learning support services need to be based on the needs of learners. In light of this, this article explores how open universities can provide standardized, personalized and diversified learning support services based on the needs of learners in the "Internet+" era.

\section{Current Deficiencies in the Learning Support Services of Open Universities}

\subsection{The Construction of Learning Support Service System Has Not Attracted Enough Attention}

Open Universities were developed from the TV University. They have been engaged in distance education for many years. Open Universities pay more attention to the construction of the didactical activities system, but they have not invested enough in the construction of the learning support service system. For example, Zhejiang Open University with 10 city-level TV universities and 59 county-level TV universities has a complete and face-to-face didactical activities system. However, Zhejiang Open University is still inadequate in the construction of the learning support service system, and lacks a special learning support service department. Zhejiang Open University is a complete learning support service and system from the school headquarters to the city-level and county-level TV universities. However, the corresponding level of learning support service center has not yet been fully established. Even the school headquarter has not established a special learning support service management center. This work is scattered among various functional departments and lacks coordination. Citylevel and county-level TV universities have not generally established one-stop learning support service institutions. The lack of relevant learning support service personnel and service equipment makes the entire learning support service system fail to establish a smooth learning support service operation and communication system. When there are communication and coordination deficiencies in the learning support service, teachers and students may fail to find the right department to solve their problems.

\subsection{The Learning Support Service Quality Assurance System Is Unsound}

American quality management master Peter F. Drucder believes that "quality is to meet needs" (He, 2018), and service quality is whether service performance meets customer expectations. The service quality guarantee system of open university distance education refers to a series of guarantee measures taken by distance education providers in order to meet the expectations of learners and meet the quality needs of all learners, so that every learner can obtain high-quality 
services. Just as the guarantee of teaching quality requires the formulation of certain standards and guarantee measures, and the guarantee of the quality of learning support services should also have a complete guarantee system, the current service quality guarantee system of open universities is not yet sound. Firstly, the monitoring mechanism supporting service quality is still in the process of continuous improvement and lacks sufficient verification of practical links. Secondly, there is discrepancy between the evaluation paradigm of learning support service quality and public expectations. In addition, the loose multi-level education system of open universities has directly led to the understanding inconsistency of standards and monitoring in learning support service quality. As a result, the quality of education and learners' recognition drop off, and the society's evaluation and expectations of the open universities also become lower and lower.

\subsection{Learning Support Services Ignore Individual Needs and Lack Initiative}

Open education generally adopts a teaching mode that combines online and face-to-face teaching. In other words, in addition to self-learning of relevant curriculum resources by students through the Internet, the school also arranges face-to-face teaching accordingly. According to the situation reported by students, course teachers often simply move the teaching content of traditional classrooms to the Internet for students to learn by themselves. The individualized problems encountered by students in the learning process cannot be answered in a timely manner, and the learning effect cannot be guaranteed. Face-toface teaching is a condensed version of full-time classroom teaching. It usually adopts didactic teaching and only explains the key content of the course. The teaching objective is mostly to pass the exam, and there is a lack of face-to-face personalized communication and discussion. In addition, although the school attaches great importance to online teaching and research activities, most of the activities are arranged in the daytime, which conflicts with the actual work of the students during the day. Therefore, there are fewer students participating and the effect is not satisfactory. In terms of teaching evaluation, although some courses have carried out formative assessment reforms, there are still many courses whose assessments are based on paper examinations and homework completion. This assessment method does not accord with the actual situation of distance education for adult students.

To conclude, the first is that in the process of learning guidance, few teachers can make personalized learning plans for learners through academic research; the second is that teachers cannot give students personalized teaching guidance according to local conditions in the process of student assistance; There is a lack of direct control and intervention of academic conditions in the supervision process. Overall, the support of the teaching process ignores individual needs and lacks initiative. 


\subsection{Personalized Support Services Can't Meet the Needs of Students}

Personalized learning support services denote a sum of various information, resources, personnel, and facilities based on individual characteristics and needs of learners after comprehensive investigation, testing and research of learners (Dai, 2012). Compared with the support services for all students, personalized support services are more able to promote the learning and development of distance students. A survey found that current teaching, learning resources, technology and other support services provided by distance education institutions are basically for all students, and personalized support services are rarely provided according to students' individual differences.

\subsection{Learning Resource Support Lacks Pertinence and Effectiveness}

Providing learning resources is the key to ensuring the effective development of distance learning. With the advancement of Internet information technology, the sources of learning resources are becoming more and more extensive. However, there are also problems. Learning resources focus mainly on quantity but ignore quality. There are a large number of simple and repetitive course resources, and there is a lack of interactive resources between teachers and students. Most of the learning resources are textual resources which are not diversified and innovative. Furthermore, learning resources lack professional and curriculum characteristics. Schools have not grasped the law of distance learning for adult in-service students or provided the resources that meet the individualized learning of students.

\section{The Effect of Internet Technology on Open University Distance Education}

The Internet is changing the world and also changing education. Open university is a new type of university supported by modern information technology, facing all members of the society, serving the construction of a lifelong education system and the construction of a learning city. The biggest difference between it and ordinary universities is the adultness of learners and the informatization of learning methods. Teachers and students are in a state of quasi-separation. The main communication channel is the Internet. Learning support service methods are subject to the development of information dissemination technology. Information technology affects the ways and means of communication between teaching and learning, and in turn, affects the ways and standards of service.

\subsection{Technology Enables Learning to Break through the Limitations of Time and Space}

In the PC era, teachers and students could use computers and Internet to make the interaction of teaching and learning easier. However, it is still limited by hardware and time. Students must use computers with Internet access and study 
or communicate with teachers and classmates through the computer. In the "Internet+" era, the emergence of mobile phones has greatly improved the communication conditions between teachers and students, and students can contact teachers or classmates as quickly as possible when they encounter problems. With the advancement of technology and the increasing popularity of the Internet, instant messaging tools (DingTalk, WeChat, QQ) have further promoted the communication between teachers and students. Abundant learning resources on the Internet enable students to break through the limitations of time and space and start learning anytime, anywhere. It can be said that the "Internet+" era has increasingly demonstrated the flexibility, autonomy, convenience and low cost of distance learning.

\subsection{Technology Changes the Learning Mode of Distance Education}

Affected by technology and traditional education models, in the current distance education courses, teachers generally provide teaching materials and carry out online teaching activities. Students can study and discuss as required, complete homework and exams, and then graduate. Fundamentally speaking, this teaching model only "moves" the real classroom to the virtual environment. Due to the large differences in learning environment and condition for learners, this kind of teaching only attaches importance to the provision of learning materials but undervalues the teaching process and evaluation. Nowadays, adult learners have grown up in a digital and information environment since they were young. They are no longer willing to learn solid knowledge that requires rote memorization. They are more willing to accept the latest and fragmented knowledge and pay more attention to learning experience and knowledge sharing. Mobile Internet-based learning can record students' browsing and learning traces and then use big data for analysis. Teachers can easily grasp students' preferences, predict the next learning plan, and provide corresponding learning content according to students' learning methods and learning progress. Finally, it can develop the correspondent learning plan.

\subsection{Technology Changes the Learning Support Service Model}

Learning support services are the characteristic of distance open education. At present, due to restrictions on funds and teachers, distance education institutions have not yet been able to provide personalized student support services. With the development of "Internet+ technology" and its in-depth application in distance education, big data and cloud computing technology can record learners' learning process, and analyze learners' learning habits and other personality characteristics. In order to provide personalized learning support services. The future learning support service model will inevitably change from a standardized service model provided by schools to a consumption-driven service model chosen by students. The object of education services is not only for student groups 
but to individual students. Technology will make personalized education services a reality.

\section{Optimal Strategies for Realizing the Value of Learning Support Services in the "Internet+" Era}

The ontological value of open universities' learning support services lies in meeting the individual learning needs of learners through a scientific service system, a complete service model, and precise service content, thereby enhancing the school's competitiveness and meeting the needs of social development.

With the continuous development of information technology and its in-depth application in distance education, many new changes and new trends have emerged in the field of distance education. Today, learners can learn anytime and anywhere. In order to better promote teaching and learning and provide learning guarantee for every student, it's time for us to change our thinking, innovate the learning support service model, strengthen the system construction of learning support services, and provide learners with standardized and personalized, diversified learning support services.

\subsection{Strengthen the Construction of Learning Support Service across Institutions}

In the learning support service system, the learning support service center, as a "one-stop" learning support service window, is a collection of various resources, personnel and related service methods related to learning support services. It can be a collection of physical spaces. The learning support service center can be equipped with relevant enrollment, teaching, management, technical personnel and necessary learning support service equipment. It can also be a collection of online spaces to realize the informatization and self-help of learning support service resources.

Open universities are the huge school-running system, like the Internet, which is open. To make it run in an orderly manner, it is necessary to establish a distance learning support service organization, that is, a learning support service center, at a hierarchical level, which can coordinate and manage all tasks of learning support services, and formulate unified technical standards and operations specification.

\subsection{Provide Standardized and Normalized Learning Support Services}

In order to ensure the effectiveness of learning support services, learning support service centers must clearly stipulate the content and links of support services, and there must be corresponding institutional norms and quality standards. Counselors, course instructors, managers and technicians who participate in support services should have clear job responsibilities and operating specifications. The main factors affecting learning support services are majors and courses, resources and platforms, facilities and technology, etc. Key links of 
learning support services include guidance services, coursework and assessment, practical teaching, specific standard requirements for graduation thesis, etc. The routine management of learning support services covers registration, student status change, make-up exams, retakes, exemption from exams, exam sign-ups, graduation certificates, etc.

University should formulate evaluation, reward and punishment systems for learning support services. With these specifications, support service work has rules to follow. Learning support services run in an orderly manner so that support service work is always in self-regulation and dynamic development, spiraling upward in dynamic development, and continuously improving service quality. Consequently, students can experience high-quality support services.

\subsection{Explore Personalized Teaching Support Services Based on Cloud Computing}

According to the characteristics of adult learners in distance education, schools should provide personalized teaching support services. First of all, schools should rationally plan the teaching progress, carefully arrange online teaching and research activities, taking into account the systematic nature of curriculum teaching and the gradual nature of student learning. Secondly, schools should provide dynamic guidance and aiding resources, as well as more inspiring and open resources in online teaching and research activities. Teachers should be conscious of guiding students in these learning support services.

The sharing and interaction nature of the Internet are integrated into distance education, and video courses are combined with online Q\&A through the ESNS system. Students can carry out online learning and interactive exercises with online devices, and assess learning outcomes immediately. Using cloud computing technology, each short video, teaching material, and online interactive exercise in the course can be regarded as an object, and every student's learning behavior and process of the "object" will be recorded by the distance learning platform and form "big data." The system analyzes, quantifies, summarizes these data systematically, and discovers the learning status of learners (Yang \& Wang, 2015). Teachers formulate appropriate learning plans for students, purposefully guide students in learning and provide personalized services.

\subsection{Construct Student-Oriented Learning Resource Support Services}

Providing high-quality and rich learning resources is the primary task of student support services. According to the learning needs of the new generation of students, it's necessary to make full use of the advantages of Internet technology and build a student-oriented learning resource support service model.

Firstly, the construction of professional resources should be planned as a whole, highlighting its characteristics. This not only requires the improvement of the curriculum system, but also needs to ensure that the courses are welcomed by the students. It is specifically implemented in the resource construction of 
each course, and the teaching resources provided are required to comply with the teaching rules of distance education and the actual situation of adult students' distance learning. Schools should provide innovative resources that meet the teaching goals of the course and can be used by students.

Secondly, learning support services should use Internet technology to develop micro-resources to meet the needs of students for mobile learning. Microresources such as micro-classes, micro-videos, course apps, etc. are short and exquisite, convenient for students to use on mobile devices. Students can use free time for fragmented learning.

Thirdly, it's essential to fully develop and utilize library resources. Students who take distance education have much more demand for information resources compared with ordinary college students. Ordinary colleges and universities basically have large-scale libraries and electronic resources. Due to funding and other reasons, the construction of libraries in distance education institutions is generally worse than that of ordinary universities. With technological progress and changes in student needs, schools should speed up the construction of distance education resource centers to provide students with a modern online learning environment and diverse information resource services.

\subsection{Create One-Stop and Diversified Services That Combine Online and Offline}

The students of open universities are mainly adults. The contradictions between work, family burden and study are prominent. The services provided to them should be linear, one-stop and diversified that combine online and offline, so that students can get academic and non-academic support services conveniently and quickly.

From an online perspective, learning support services should be based on a one-stop and professional website that provided services including sign-up, course selection, payment, assessment, study evaluation, score query and graduation thesis. Specific within a course, items should include: course description, teacher introduction, syllabus, implementation plans, teaching guidance, daily homework and interactive discussion areas. The management platform should include enrollment registration, program introduction, rules and regulations, information announcements, consulting services, learning communities, counselor columns, etc. The professional website, course website and management website are integrated into one, and the three websites are controlled by the learning platform. The professional website provides the "one-stop" service function for professional learning. The course website provides the "one-stop" service function for course learning, and the management website provides a "one-stop" service function for information query. This provides comprehensive, one-stop, and diversified services online.

From the offline point of view, the establishment of a learning guidance center is responsible for the "one-stop" and all-round provision of support services for registration, textbook collection, program orientation, tutoring arrangements, 
course assessment, student status management, graduation thesis, and graduation certificate. This will provide students with more convenient and considerate service.

\section{Conclusion}

The "Internet+" era has brought the modernization of distance education. Improving the quality of learning support services is an inevitable requirement for the connotation construction and sustainable development of open universities. The learning support services of open universities should have richer connotative and student-centered features, and provide learners with standardized, diversified, and personalized learning support services in teaching, management, resources and technology sectors.

\section{Acknowledgements}

My thanks to the anonymous reviewers for reading and commenting on the early drafts of this article.

\section{Conflicts of Interest}

The author declares no conflicts of interest regarding the publication of this paper.

\section{References}

Bath, J. (1979). Correspondence Education in the Light of a Number of Contemporary Teaching Models. LiberHer-Mods.

Dai, J. (2012). Teacher Educational Technology Ability Network Training Personalized Learning Support Service Strategy Research. Master Thesis, Nanjing Normal University.

Ding, X. F. (2001). Distance Education (p. 217). Beijing Normal University Press.

He, Y. M. (2018). Research on Distance Education Learning Support Service Innovation Model in "Internet Plus" Era. Journal of Yunnan Open University, 1, 7-11.

Sewart, D. (1978). Continuity of Concern for Student in a System of Learning at a Distance. Ferunibersitat.

Tang, W., Zuo, K. J., \& Zhang, D. (2020). Study Support Service in the Open University and Ways of Realizing the Service Value. Adult Education, 5, 28-36.

Yang, X. X., \& Wang, W. (2015). Research on MOOC-Based Distance Education Mode. China Educational Technology and Equipment, 2, 128-130.

Yang, Z. J. (2011). Central Radio and Television University in a Historical Perspective. China Higher Education, 9, 10-12. 